\title{
An Analysis of Polysemy of "anding-andingen" Proverb in Karo Language: Problems of Natural Semantic MetaLanguage
}

\author{
Karisma E. Tarigan ${ }^{1}$, Mulyadi ${ }^{2}$ \\ ${ }^{1,2}$ Universitas Sumatera Utara, Indonesia \\ erick_tarigan2006@yahoo.com,mulyadi@usu.ac.id
}

\begin{abstract}
This article aims at proposing a way to identify polysemy 'andingandingen' or proverb in bahasa karo. The writer has an interest to use proverb or anding-aningen in this study because in proverb contains a lot of semantic meaning. This study was conducted using the descriptive qualitative approach in nature; therefore it only describes the semantic knowledge theory. The results of this study indicate that the element DO may occur either with a subject (Actor) alone with a second (Patient) argument as well (in English, as DO TO). It opened the way for a new semantically-inspired approach to grammar constructions. An analysis of ' $X$ does this' as ' $X$ can say this' and of ' $A$ because $B$ ' as if not $B$, the not $A$ ', the writers admitted that both $D O$ and BECAUSE into the stable of semantic primitives. A similar entailment-like relationship obtains between PEOPLE and SOMEONE, but there is at least one significant syntactic difference, namely, that PEOPLE cannot occur with quantifier ONE.
\end{abstract}

Keywords

teaching materials; explanatory text, needs analysis of learning

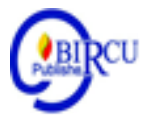

\section{Introduction}

There are many approaches in the study of semantics and many of them offer their representational system or metalanguage in order to explain lexical meanings. Human creativity in using language is not only seen through new creation of words, but also through various meanings represented by a single phonological form. To provide basic human needs to interact with their surroundings, language is always changing and developing. Words can take on new meanings, shrinking or (more commonly) extending the domain of their reference (Finegan, 1992:95).

The word semantics has ultimately prevailed as a name for the doctrine meaning, particulary of linguistics meaning. Semantic is the study of meaning. It is a wide subject within the general study of language. It is important for understanding language in social contexts, as these are likely to affect meaning, and for understanding varieties of English and effect of style. It is thus one of the most fundamental concepts in linguistics. The study of semantics includes the study of how meaning is constructed, interpreted, clarified, obscured, illustrated, simplified negotiated, contradicted and paraphrase.

A theory that focuses on deconstructing the meaning of words until the core meaning founded is called NSM (Natural Semantic Metalanguage). Goddard (2008) explaining that NSM is a system that deconstructs meaning by using the universal accepted semantic primes. It's means that, NSM is a tool in finding the core meaning of words. He also explains NSM is a tool which is used to define something that is indefinable.

Another way to identify the meaning of words using NSM is by using polysemy. Whereas, Goddard and Wierzbicka (2014:13) define polysemy is when one word is used to 
express two different semantic primes. In fact that, semantic prime is the core meaning of all the words in all of the language in the world, not all words can use one semantic prime and capture the meaning perfectly.

The metaphorical use of words often leads to new meanings that come to seem perfectly natural. Then a form of language with more than one related meaning is called polysemy. Polysemy is described as the association of two or more related senses with a single word form. A further issue that an account of polysemy representation must address is how the relations between the polysemy senses are represented in the mental lexicon. The senses of the word are related to each other in a certain degree. Polysemy lexical items can be represented as a network of senses centered on a primary, prototypical sense.

Any theory of polysemy needs a rigorous means of determining whether a word has more than one meaning and, if so, just how many meanings it has. On this principle, a word is polysemy if its meaning is susceptible of more than a single definition. But since the sense divisions produced by a content-based principle will be differ according to both metalanguage chosen, and the particular interpretation adopted of semantic content of any given word, there would beseem to be an uncomfortable degree of indeterminacy in the theorizing of nature of the divisions between different word senses. Riemer (1972:5) explains that counterproductive, and that attention to the wider problematic of cognitive science can be illuminating for the very questions that have newly emerged as topics of scrutiny in cognitive semantics. Thus, cognitive semanticists' recent examinations of the notions of mental representation, conceptual content (mental imagery), polysemy and metaphor can all be fruitfully brought into contact with sometimes longstanding debates in cognitive science.

Semantic analysis in NSM (Natural Semantic Metalanguage) is accomplished through the reductive paraphrase of definition into a metalanguage consisting of a subset of ordinary language expression claimed to represent universal primitive concept the "few thought" from which all the others can be derived. Wierzbicka (2006) state semantic analysis must be conducted in natural language; complex meaning can be stated in terms of simpler ones (reductive paraphrase); the NSMs of all language are isomorphic. Over the period of 30 years of extensive empirical, cross-linguistic investigation, She and her colleagues have collected a set of 60 lexical universal (e.g., A LONG TIME, DO, GOOD, PEOPLE, etc.) this "minilexicon' of semantic primes and the manner of their combination constitute a metalanguage. The metalanguage has a wide range of application, such as intercultural communication, language acquisition and teaching, language typology, legal semantics, and lexicography.

Generally speaking, Hristova-Gotthardt and Varga (2015) argued that semantics should not be understood in terms of meaning, but the study of meaning, or science of meaning, in this understanding, thus would not be the object of study, but the discipline of studying the object; and since the object in this case (the proverb), is a linguistics expression, from this perspective, any attempt to explain or to interpret a proverb, i.e., to describe its meaning, could thus be classified as being semantic, and any description of proverb meaning would fall into the field of proverb semantic. Tarigan (2019) stated that English has tenses to mention something. It would be different auxiliary when the time in present, past and future. For example, some will focus on testing particular theoretical claims; others on developmental, cognitive or social factors in the acquisition process; others on the development of a particular feature of language; and others on what we might learn about language development from studying what goes wrong in particular situations (Tarigan, 2019). 


\section{Review of Literatures}

\subsection{Semantic}

Mulyadi (2003:1) claimed that each language has thousands of vocabularies that can be classified into a number of grammatical categories or classes. Members of each category are usually given the same name because of the similarity in semantic behavior, which reflects general meanings. (Each language has thousands of vocabularies that can be classified into a number of grammatical categories or classes. Members of each category are usually given the same name because of the similarity in semantic behavior, which reflects general meanings). Slavcheva (2013:245) states that the systematic semantic representation of events, encoded as verbal predicates in natural language, requires the definition of that layer of the metamodel inheritance structure, which is necessary for building the specified semantic descriptors of the lexically encoded predicates, that is, the descriptors that constitute the genuine entries in a semantic lexicon. Lehrer, et.al. (2012:7) argued that the meaning of a word is a configuration of semantic primitives, and as such does not depend on the meaning of other words in the lexicon. The value of semantic fields lies in the grouping of words thought to be similar in meaning, for 'to establish what the meaning of a word is one has to compare it with the meaning of other, intuitively related words.

Riemer (2008:182) stated that four types of semantic extensions, that is: (1) Metaphorical applications of the core verbal meaning (M), (2) Effect metonymies: metonymic extensions to the effect of the action of the verb (m/effect), (3) Context metonymies: metonymic extensions to the context in which the action of the verb occurs ( $\mathrm{m} /$ context), and (4) Constituent metonymic extensions by selection of a constituent of the verbal event (m/selection). Furthermore, he stated that even a theory which wishes to remain uncommitted on the formal polysemy or monosemy of a word's semantic representation needs some guarantee that the semantic units it informally identifies and names within the meaning of the word are not arbitrary, and that their different names do not belief a deeper identity. The inability to meet this challenge is a problem of semantic theory.

\subsection{Natural Semantic Metalanguage}

Goddard (2018:305) stated that meanings in semantics are divided into two types, namely T-semantics (truth-semantics) and U-semantics (understanding semantics). Natural semantic metalanguage firmly in the U-semantics tradition. It is semantics of human understanding. Nevalainen and Traugott (2012:435) explained that the NSM analysis of meaning is based on 'reductive' paraphrase, in the sense that complex meanings are 'reduced', in a systematic way, to simple or simpler ones. It attempts to say the same thing' in a paraphrase composed of maximally simple, intelligible, and cross-translatable words (semantic primes), thereby laying bare the semantic content compressed in the original expressions. Goddard, et. al. (2017:36) explained that Natural Semantic Metalanguage is a paraphrase technique, with its first-person orientation, is well adapted to representing nuances of subjective meaning. Many emotion predicates can be explicated using the same or a similar template, by varying the content of the prototypical thought(s) and the nature and intensity of the linked feeling. For example: he was happy. 
Table 1. The Example of Natural Semantic

\begin{tabular}{|l|l|}
\hline he (=this someone) thought like this for some time at this time. & Thought \\
\hline $\begin{array}{l}\text { 'many good thing are happening to me now as I want I can do many } \\
\text { things now as I want this is good.' }\end{array}$ & $\begin{array}{l}\text { Thought } \\
\text { Content }\end{array}$ \\
\hline at the same time this someone felt something good because of it. & Feeling \\
\hline like people often feel when they think like this. & Typicality \\
\hline
\end{tabular}

Similarly, Goddard and Wierzbicka (1994:8) stated that the aim of NSM research is to find the smallest necessary set of primes, to find the "atoms" and to decompose all the "molecules." This search for a "set of indefinables" and a "set of defining concepts" that (ideally) is the same leads to a "culture-free semantic metalanguage." Further, "to explain any meanings we need a set of presumed indefinables, and to explain meanings across languages and across cultural boundaries we need a set of presumed universals." They also added the principles of NSM theory:

1. Semiotic principle. Signs are composed of signs and meanings are composed of other meanings. What philosophers know as a fully intentional concept of meaning.

2. Principle of discrete and exhaustive analysis. This contrasts with componential analysis, and "scalar notions" such as fuzzy set theory. "Any complex meaning can be decomposed into a combination of discrete other meanings, without circularity and without residue.

3. Semantic primitive principle. This follows from I and II and posits a "finite set of undecomposable meanings.

4. Natural language principle. Semantic primitives are a "minimal subset of ordinary natural language.

5. Expressive equivalence of NSMs. "Complete inter-translatability between NSMs." Equivalent expressive power in every language.

6. Isomorphism of NSMs. There will be a fairly straightforward one-to-one correspondence between primes cross-linguistically.

7. Strong lexicalization hypothesis. Primitives "can be expressed through a distinct word, morpheme, or fixed phrase in any language."

\subsection{Semantic Primes}

Goddard (2018:231) defined that the term 'semantic primitives' refers to meanings which are so simple that they cannot be further explained or defied. They are analogous to chemical elements, which cannot be broken down into any other elements. A semantic primitive, in principle, is a meaning which resists further explanation or decomposition. Farese (2019:13) stated that The Natural Semantic Metalanguage (NSM) is a reduced language used to define the meanings of words. This mini-language differs from ordinary languages in that it consists of only sixty-five semantic primes, primitive concepts intended to represent the semantic core shared by all languages. The criteria for identifying the primes are three: (i) a prime is an indefinable concept, that is, it is impossible to say what it means without ending up with circular definitions, (ii) a prime is a basic concept, that is, a concept which cannot be further decomposed or reduced into a simpler concept, (iii) a prime has a lexical exponent in a natural language which is directly crosstranslatable.

Allan (2010:611) categorized the syntactic properties of primes can be seen as falling into three kinds. The first type is basic combinatorics, for example, the fact that substantive primes such as something/thing, someone/person, and somewhere/place, and relational 
substantives such as part and kind can combine with specifiers to form semantic units: this thing, the same person, somewhere else, one part, many kinds, and so on. The second type is an account of basic and extended valencies; for example, the fact that the prime do can occur not only in its basic frame someone did something, but also in extended frames such as someone did something to something (or to someone) and someone did something to something with something. Valency options, which are argument-like, are distinguished from adjuncts such as temporal and locational phrases along conventional lines. The third type of syntactic properties concerns the propositional complement possibilities of primes such as know, want, and think, for example, that know can occur in the frame I know that something happened in this place and that want can occur in frames like I want to do something to happen.

Sharifian and Palmer (2007:108) classified the syntactic primes for three semantic primes:

Table 2. The Syntactic Primes for Three Semantic Primes

\begin{tabular}{|l|l|}
\hline \multirow{3}{*}{ Do: } & X does something. \\
\cline { 2 - 2 } & X does something to someone [patient] \\
\cline { 2 - 2 } & X does something to someone with something [patient+instrument] \\
\hline \multirow{3}{*}{ Happen: } & Something happens \\
\cline { 2 - 2 } & Something happens to someone [undergoer] \\
\cline { 2 - 2 } & Something happens somewhere [locus] \\
\hline Say: & X says something \\
\hline & X says something to someone [addressee] \\
\hline & X says something about something [locutionary topic] \\
\hline & X says: “....." [direct speech] \\
\hline
\end{tabular}

According to Mey (2009:995), "The term "speech act verbs" has variously been defined as applying either to all verbs used to refer to any type of verbal behavior or to the much smaller sub set of verbs expressing specific speaker attitudes. Speech act verbs are used to refer to situations characterized by the following features or situational roles: a speaker $(\mathrm{S})$, a hearer $(\mathrm{H})$, a set of speaker attitudes, and an utterance (Utt) mostly containing a proposition $(\mathrm{P})$. These four elements are parts of any situation referred to by speech act verbs and constitute the unifying feature of the meaning of these verbs." Moreover, Wierzbicka (1987:16) explained that the primary function of speech act verbs consists in interpreting people's speech acts, not in performing speech acts. Whether we say "I order you to do it!" or simply "do it!" we expressing the following attitude:

I want you to do it

I assume that you have to do what I say I want you to do

If we say, however "he ordered her to do it" we convey something more complex.

Roughly speaking, we convey this:

He said something to her that meant "I want you to do it"

He said it as if he wanted to say "I assume that you have to do what I say I want you to do".

A somewhat more accurate (but still approximate) analysis would take the following form (Wierzbicka 1974):

$\mathrm{X}$ ordered $\mathrm{Y}$ to do $\mathrm{Z}$

$\mathrm{X}$ said something to $\mathrm{Y}$

Imagining that I want to say it to you I could say this: 
I want you to do $\mathrm{Z}$

I assume that you have to do what I say I want you to do.

There are 37 groups of speech act verbs list given by Wierzbicka (1974:33). These are:

Table 3. Speech Act Verbs in Semantic Primes

\begin{tabular}{|c|c|c|}
\hline Order & $:$ & command, demand, tell2, direct, instruct, require, prescribe. \\
\hline $\mathrm{Ask}_{1}$ & : & $\begin{array}{l}\text { request, beg, beseech, implore, appeal, plead, intercede, } \\
\text { apply, urge, persuade/ dissuade, convince. }\end{array}$ \\
\hline $\mathrm{Ask}_{2}$ & $:$ & inquire/ enquire, interrogate, question, query. \\
\hline Call & $:$ & summon, invite, call on, call for, order 2 , book, reserve \\
\hline Forbid & : & $\begin{array}{l}\text { prohibit, veto, refuse, decline, reject, rebuff, renounce, } \\
\text { cancel, resign, dismiss. }\end{array}$ \\
\hline Permit & $:$ & $\begin{array}{l}\text { allow, consent, accept, agree, approve, disapprove, authorize, } \\
\text { appoint. }\end{array}$ \\
\hline Argue & $:$ & $\begin{array}{l}\text { disagree, refute, dispute, contradict, counter, deny, recant, } \\
\text { retort, quarrel. }\end{array}$ \\
\hline Reprimand & $:$ & $\begin{array}{l}\text { rebuke, reprove, admonish, reproach, nag, scold, abuse, } \\
\text { insult. }\end{array}$ \\
\hline Mock & $:$ & ridicule, joke. \\
\hline Blame & $:$ & criticize, condemn, denounce, deplore, curse \\
\hline Accuse & $:$ & charge, challenge, defy, dare \\
\hline Attack & $:$ & Defend \\
\hline Warn & : & threaten, blackmail \\
\hline Advise & $:$ & counsel, consult, recommended, suggest, propose, advocate \\
\hline Offer & $:$ & volunteer, grant, give \\
\hline Praise & $:$ & commend, compliment, boast, credit \\
\hline Promise & $:$ & pledge, vow, swear1, vouch for, guarantee \\
\hline Thank & : & $\begin{array}{l}\text { apologize, greet, welcome, farewell, good bye, say, introduce, } \\
\text { bless, wish, congratulate. }\end{array}$ \\
\hline Forgive & $:$ & excuse, justify, absolve, pardon, convict/ acquit, sentence \\
\hline Complain & $:$ & protest, object, moan, bemoan, lament, bewail \\
\hline Exclaim & : & enthuse, exult, swear2, blaspheme. \\
\hline Guess & $:$ & $\begin{array}{llll}\text { bet, presume, suspect, suppose, } & \text { wonder, } & \text { speculate, } \\
\text { conjecture, predict, forecast, prophesy. } & & \\
\end{array}$ \\
\hline Hint & $:$ & imply, insinuate \\
\hline Conclude & $:$ & $\begin{array}{l}\text { deduce, infer, gather, reckon, estimate, calculate, count, prove, } \\
\text { compare. }\end{array}$ \\
\hline Tell $_{1}$ & $:$ & report, narrate, relate, recount, describe, explain, lecture. \\
\hline Inform & $:$ & inform on, notify, announce, reveal \\
\hline Sum up & $:$ & summarize, recapitulate. \\
\hline Admit & $:$ & acknowledge, concede, confess, confide. \\
\hline
\end{tabular}




\begin{tabular}{|l|l|l|}
\hline Assert & $:$ & affirm, claim, maintain, contend, state, testify. \\
\hline Confirm & $:$ & assure, reassure. \\
\hline Stress & $:$ & emphasize, insist, repeat, point out, note, remind, add. \\
\hline Declare & $:$ & pronounce, proclaim, decree, profess, vote, resolve/ decide. \\
\hline Baptize & $:$ & christian, name, excommunic ate \\
\hline Remark & $:$ & comment, observe. \\
\hline Answer & $:$ & Reply \\
\hline Discuss & $:$ & debate, negotiate, bargain \\
\hline Talk & $:$ & converse, chat, gossip. \\
\hline
\end{tabular}

The table below will explain about the grouped into the related categories based on Goddard (2008:61).

Table 4. The Categories of Semantic Primes

\begin{tabular}{|l|l|}
\hline $\begin{array}{l}\text { I-ME, YOU, SOMEONE, SOMETHING- } \\
\text { THING, PEOPLE, BODY }\end{array}$ & substantives \\
\hline KIND, PART & $\begin{array}{l}\text { relational } \\
\text { substantives }\end{array}$ \\
\hline THIS, THE SAME, OTHER-ELSE & determiners \\
\hline $\begin{array}{l}\text { ONE, TWO, SOME, ALL, MUCH-MANY, } \\
\text { LITTLE, FEW }\end{array}$ & quantifiers \\
\hline GOOD, BAD & evaluators \\
\hline BIG, SMALL & descriptors \\
\hline $\begin{array}{l}\text { KNOW, THINK, WANT, DON'T WANT, } \\
\text { FEEL, SEE, HEAR }\end{array}$ & mental predicates \\
\hline SAY, WORDS, TRUE & speech \\
\hline $\begin{array}{l}\text { DO, HAPPEN, MOVE, TOUCH } \\
\text { (SOMEONE)'S, BE (SOMEONE/SOMETHING) }\end{array}$ & $\begin{array}{l}\text { actions, events, } \\
\text { movements, contacts }\end{array}$ \\
\hline LIVE, DIE & life and death \\
\hline $\begin{array}{l}\text { WHEN-TIME, NOW, BEFORE, AFTER, A } \\
\text { LONG TIME, A SHORT TIME, FOR SOME } \\
\text { TIME, MOMENT }\end{array}$ & time \\
\hline $\begin{array}{l}\text { WHERE-PLACE, HERE, ABOVE, BELOW, } \\
\text { FAR, NEAR, SIDE, INSIDE }\end{array}$ & space \\
\hline NOT, MAYBE, CAN, BECAUSE, IF & logical concepts \\
\hline VERY, MORE & intensifier, augmentor \\
\hline LIKE-WAY-AS & similarity \\
\hline
\end{tabular}

Notes: (i) primes exist as the meanings of lexical units (not at the level of lexemes) (ii) exponents of primes may be words, bound morphemes, or phrasemes, (iii) they can be formally complex (iv) they can have combinatorial variants (alloxeles) (v) each primes has well-specified syntactic (combinatorial) properties. 


\section{a. Polys emy}

Ji and Xiao (2013:459) defined that polysemy the capacity for a sign to have multiple meanings, but can be a 'semantic primitives' and 'derived meanings.' Karaman (2003:49) assumed that in polysemy, senses share similar characteristics. They are semantically related to each other and belong to the same system of concepts. In the case of polysemy, it is defined that the same acoustic image can be the symbol for different realities. The use of polysemy is the result of exploiting existing resources of a language. This phenomena where an existing linguistic label becomes attached to a new concept is also referred to as re-semanticisation.

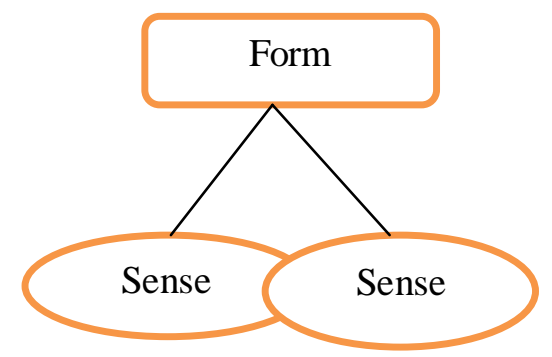

Figure 1. The Meaning of Polysemy

\section{b. Types of Polys emy}

Srinivasan and Snedeker (2013) state that forms of polysemy in English:

Table 5. Forms of Polysemy in English

\begin{tabular}{|c|c|}
\hline Relation and Participating Words & Examples \\
\hline $\begin{array}{l}\text { Natural Kind/Food } \\
\text { (chicken, turkey, corn, etc) }\end{array}$ & $\begin{array}{l}\text { The chicken walked outside/ } \\
\text { The chicken was delicious }\end{array}$ \\
\hline $\begin{array}{l}\text { Material/Product } \\
\text { (glass, tin, iron, etc) }\end{array}$ & $\begin{array}{l}\text { Watch out for the broken glass/ } \\
\text { She drank juice from the glass }\end{array}$ \\
\hline $\begin{array}{l}\text { Object/Content } \\
\text { (book, magazine, DVD, etc) }\end{array}$ & $\begin{array}{l}\text { The book is too heavy to carry/ } \\
\text { The book is very provocative }\end{array}$ \\
\hline $\begin{array}{l}\text { Container/Contents } \\
\text { (pot, bowl, box, etc) }\end{array}$ & $\begin{array}{l}\text { She cleaned the pot using a sponge/ } \\
\text { She stirred the pot with a spoon }\end{array}$ \\
\hline $\begin{array}{l}\text { Space/Time } \\
\text { (short, in, around, etc) }\end{array}$ & $\begin{array}{l}\text { The couch is too shortl } \\
\text { Our time together was too short }\end{array}$ \\
\hline $\begin{array}{l}\text { Body part/Object part } \\
\text { (leg, arm, back, etc) }\end{array}$ & $\begin{array}{l}\text { He broke his leg while skiing/ } \\
\text { That chair has a broken leg }\end{array}$ \\
\hline $\begin{array}{l}\text { Person/Product } \\
\text { (Picasso, Camus, Mozart, etc) }\end{array}$ & $\begin{array}{l}\text { Picasso was born in 1881/ } \\
\text { That museum has a Picasso }\end{array}$ \\
\hline $\begin{array}{l}\text { Place/Institution } \\
\text { (White house, Wall street, City hall, etc) }\end{array}$ & $\begin{array}{l}\text { The White House is being painted/ } \\
\text { The White House will make a decision }\end{array}$ \\
\hline $\begin{array}{l}\text { Place/Event } \\
\text { (Vietnam, Waterloo, Woodstock, etc) }\end{array}$ & $\begin{array}{l}\text { Vietnam shares a border with China/ } \\
\text { He championed civil rights during Vietnam }\end{array}$ \\
\hline
\end{tabular}

\section{Research Methods}

The research design was in the form of descriptive qualitative research and it is a part of case study. A descriptive research was to describe and interpret what kind of phenomena in language found based on data. The main source of data could be found in 
printed media, such as website of idiomatic, dictionary online, and written online local magazine by using Karo Language. The researcher used a scientific approach in Natural Semantic Metalanguage in the Categories of Semantic Primes (Table 1) and The Speech Act Verbs in Semantic Primes (Table 2) to reveal the function of polysemy in Karo Language and determine the causality in the Forms of Polysemy (Table 4). The researchers were in the form of human instrument model who knew about Natural Semantic Metalanguage (NSM) in Bahasa Indonesia and lived in Karonese culture to ensure the data was plausible, credible, and trustworthy. The focus was to explore the experiences of novice human instruments regarding to beliefs and values which had been agreed by all Karonese and it was considered as their way of life.

Mulyadi and Siregar (2006:72) explained that "teori NSM diterapkan pada data bahasa Indonesia untuk menjelaskan model aplikasinya. Dalam analisis makna diikuti prosedur penelitian sebagai berikut: (1) menentukan makna asali dari kata-kata yang akan dianalisis, (2) mencari polisemi yang tepat dari maknanya, (3) mengungkapkan property semantic yang lain di dalam makna kata tersebut disertai bukti-bukti sintaksis dan semantic, (4) membandingkan properti semantis kata-kata yang dianggap bertalian untuk memperlihatkan persamaan dan perbeedaan maknanya, dan (5) membentuk Semantik Metalanguage Universal berdasarkan properti semantis yang ditemukan, dan (6) memparafrase atau mengeksplikasi makna kata-kata tersebut." (NSM theory is applied to Indonesian data to explain the application model. In meaning analysis, the following research procedures are followed: (1) determining the original meaning of the words to be analyzed, (2) looking for the correct polysemy of its meaning, (3) revealing other semantic properties in the meaning of the word accompanied by evidence syntax and semantics, (4) comparing the semantic properties of words that are considered related to show the similarities and differences in their meanings, and (5) forming Universal Semantic Metalanguage based on the semantic properties found, and (6) paraphrasing or explicating the meanings of these words).

\section{Discussion}

NSM is used to find out the polysemy of the combined semantic primes to find out the core meaning of words in proverb karo language that are contain of semantic primes. There results of semantic primes in proverb karo language can be seen in below: Proverb in Karo language:

\section{Ngasuhi \\ anak arimo, \\ jukut \\ anak Harimau Daging \\ nakanna \\ memelihara \\ makanannya}

Raising the tiger cubs, the food is meat

'Memelihara'/ raising

$\mathrm{X}$ do to $\mathrm{Y}$

$\mathrm{Y}$ happen because of $\mathrm{X}$

Polisemi: menjaga, merawat, membesarkan,

Nonpolisemi: melestarikan, mengembangkan, menumbuhkan.

a) Speech Act Verbs in Semantic Prime: -

b) The Categories of Semantic Prime: DO [ACTION]

c) Type of Polysemy: Place/Event 


\begin{tabular}{|l|}
\hline$X$ do something to $Y$ \\
\hline$X$ do something to $Y$ [patient] \\
\hline$X$ do something to $Y$ with something [patient +instrument] \\
\hline$X$ do $Y$ with something \\
\hline$X$ do $Y$ for someone else \\
\hline $\mathrm{X}$ do $Y$ for something else \\
\hline Because $X$ do something, $Y$ feels something toward $X$ \\
\hline$Y$ want $X$ because $X$ do something to $Y$ \\
\hline$Y$ happen because of $X$ \\
\hline$Y$ think of $X$ because $X$ do something to $Y$ \\
\hline$Y$ feel something to $Y$ because $X$ think of $Y$ \\
\hline$X$ can part of $Y$ to do something because $Y$ think of $X$ \\
\hline$X$ can do something to $Y$ \\
\hline It is good $Y$ think of $X$ \\
\hline
\end{tabular}

2. Talu

Mengalah si rukur

det. Pikiran

\section{Give in the tinker}

Meaning: "Tidak ingin melakukan perdebatan dengan seseorang"

Do not want to debate with someone

Mengalah

Polysemy: menyerah, mengacuhkan,

Nonpolysemy: mundur, membatasi, menengah, menyekat

a) Speech Act Verbs in Semantic Prime: Forgive

b) The Categories of Semantic Prime: HAPPEN [EVENTS]

c) Type of Polysemy: Place/Event

\begin{tabular}{|l|}
\hline$X$ think something like this: \\
\hline Because of this, $X$ feels something to $Y$ \\
\hline Because of this, $X$ wants to do something to $Y$ \\
\hline When $X$ feels like this, $Y$ thought of $Y$ \\
\hline$Y$ wants $X$ to do something \\
\hline Something good happened because of $X$ do something to $Y$ \\
\hline Because of this, $X$ feels something very bad to $Y$ \\
\hline$X$ think of $Y$ because $Y$ wants $X$ to do something \\
\hline$Y$ feels $X$ true because of this \\
\hline$X$ cannot do something to $Y$ \\
\hline$Y$ cannot think of something because of $X$ \\
\hline$X$ far from $Y$ \\
\hline It would be good if $X$ do something to $Y$ \\
\hline$X$ feels inside because of $Y$ \\
\hline
\end{tabular}




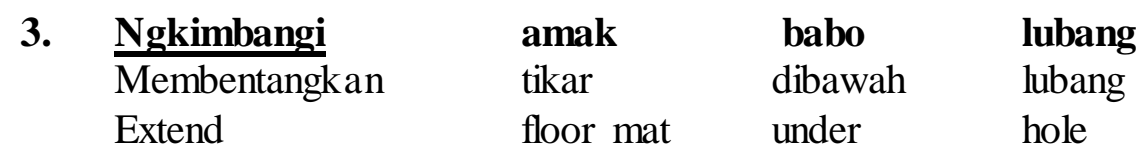

Membentangkan tikar dibawah lubang

Laying a floor mat under the hole

Berbuat kebaikan tetapi tidak tulus

Membentangkan/ngkimbangi

Polysemy: meletakkan, menempatkan, memasang

a) Speech Act Verbs in Semantic Prime: -

b) The Categories of Semantic Prime: DO [ACTION]

c) Type of Polysemy: Place/Event

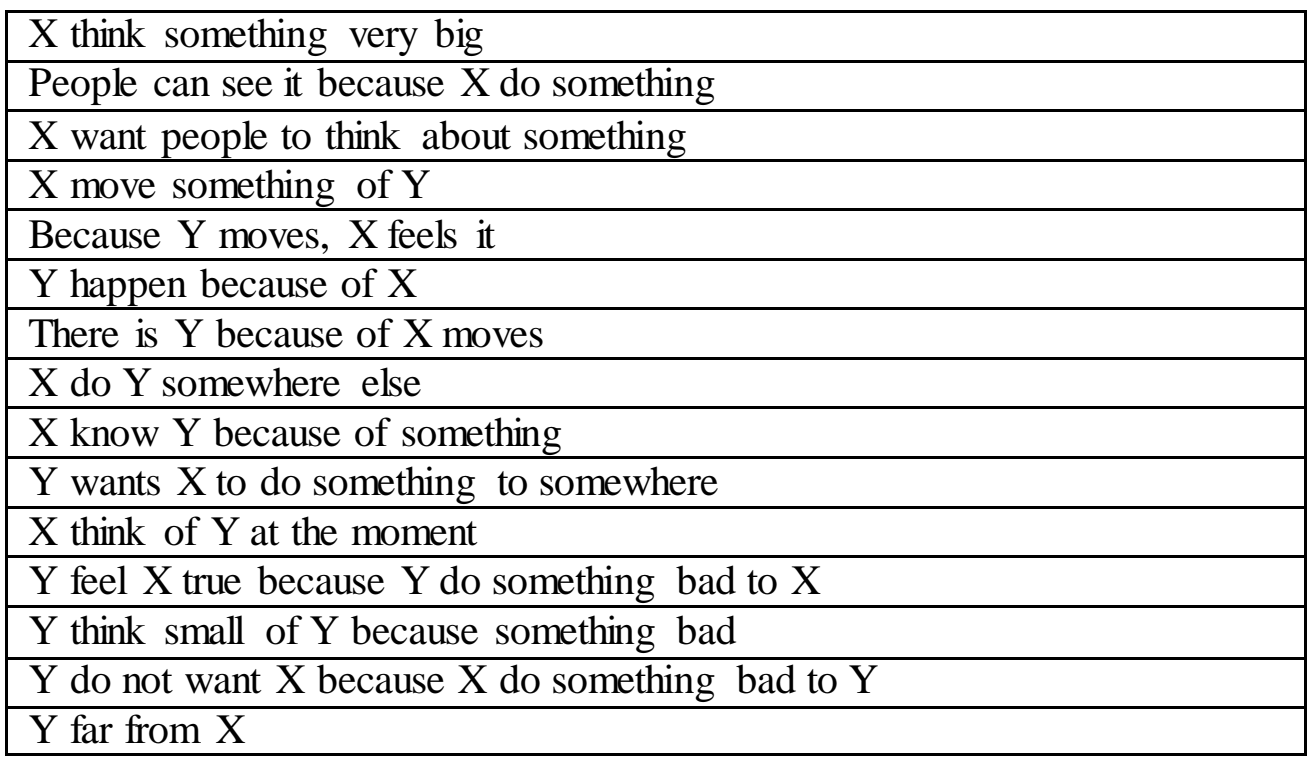

\begin{tabular}{|c|c|c|c|c|c|c|}
\hline $\begin{array}{l}\text { Adi } \\
\text { Kalau } \\
\quad \text { If }\end{array}$ & $\frac{\frac{\text { ngalo }}{\text { menerima }}}{\text { take in }}$ & $\begin{array}{l}\text { la } \\
\text { tidak } \\
\text { no }\end{array}$ & $\begin{array}{l}\text { rido, } \\
\text { untung, } \\
\text { profit }\end{array}$ & $\begin{array}{l}\text { ngalar } \\
\text { bayar } \\
\text { pay }\end{array}$ & $\begin{array}{l}\text { la } \\
\text { tidak } \\
\text { no }\end{array}$ & $\begin{array}{l}\frac{\text { rutang }}{\text { berhutang }} \\
\text { owe }\end{array}$ \\
\hline
\end{tabular}

If we accept what is not our right, then we will pay what is not our debt.

Kalau kita menerima yang bukan hak kita, maka kita akan membayar yang bukan hutang kita.

\begin{tabular}{|l|}
\hline $\mathrm{X}$ think something very big \\
\hline People can see it because X do something bad \\
\hline $\mathrm{X}$ want people to think about something bad \\
\hline $\mathrm{X}$ know anything about Y \\
\hline Because there is Y, the same thing happens to people \\
\hline Y happen because of X \\
\hline People may think bad of X \\
\hline People more do bad to X because X feels Y wants to do it \\
\hline If X do something bad, people feel X \\
\hline Y say something of X to people \\
\hline
\end{tabular}




\begin{tabular}{|l|}
\hline Y do not want feel good of $\mathrm{X}$ \\
\hline $\mathrm{X}$ feel $\mathrm{Y}$ true because $\mathrm{Y}$ do something good to $\mathrm{X}$ \\
\hline People think small of $\mathrm{X}$ because something bad \\
\hline $\mathrm{X}$ may do bad things to people \\
\hline $\mathrm{X}$ far from people \\
\hline
\end{tabular}

5. $\mathrm{Si}$

Saling

Each other

si

saling eachother

\section{agengen}

arang

charcoal

kuningen

obat tradisional

traditional medicine radu

bersama

together

radu

bersama

together mbiring,

hitam,

black

megersing

warna/kuning

yellow

if we blame eachother it will be bad, doing good will be mutually beneficial

Kalau kita menjelekkan sama-sama buruk, saling berbuat baik saling menguntungkan Siagengen dan Sikuningen atau menjelekkan dan menghargai.

a) Speech Act Verbs in Semantic Prime: Remark

b) The Categories of Semantic Prime: GOOD, BAD [EVALUATORS]

c) Type of Polysemy: Person/Product

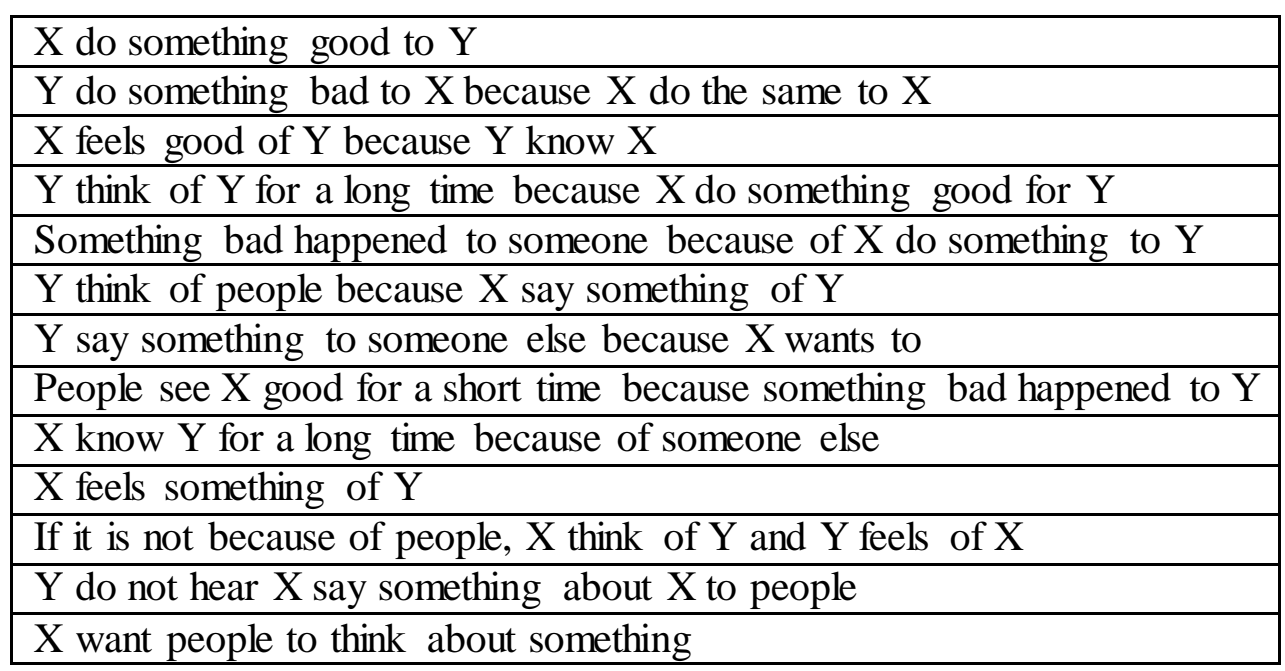

\section{Conclusion}

The main principle of semantic primes approach to Karo Language can be paraphrased something happened to Karonese cultures. This reveals in the concept that semantic primitives can have alternative 'valency options', for instance: that the element DO may occur either with a subject (Actor) alone with a second (Patient) argument as well (in English, as DO TO). It opened the way for a new semantically-inspired approach to grammar constructions. An analysis of ' $X$ does this' as ' $X$ can say this' and of 'A because B' as if not B, the not A', the writers admitted that both DO and BECAUSE into the stable of semantic primitives. A similar entailment-like relationship obtains between PEOPLE and SOMEONE, but there is at least one significant syntactic difference, namely, that PEOPLE cannot occur with quantifier ONE. It is the most of the 'someones' that one deals with in everyday life, as a matter of the fact, human beings (PEOPLE). 


\section{References}

Allan, K. 2010. Concise Encyclopedia of Semantics. Amsterdam: Elsevier.

Farese, G.M. 2019. Italian Discourse: A Cultural Semantic Analysis. Lanham: Lexington Books.

Goddard, C., \& Wierbicka, A. 1994. Semantic and Lexical Universals: Theory and Empirical Findings. Amsterdam: John Benjamin Publishing.

Goddard, C. 2008. Cross-Linguistics Semantics. Amsterdam: John Benjamin Publishing.

Goddard, et. al. 2017. The Semantics of Evaluational Adjectives: Perspectives from Natural Semantic Metalanguage and Appraisal. Nathan: Griffith University.

Goddard, C. 2018. Ten Lectures on Natural Semantic Metalanguage: Exploring Language, Thought, and Culture Using Simple, Translatable Words. Brill: Leiden.

Ji, D., \& Xiao, G. 2013. Chinese Lexical Semantics. Switzerland: Springer.

Karaman, B. I. 2003. Polysemy in Natural Language: Case Studies on Structural Description of Polysemous Lexemes in English, German, and Turkish. Guildford: University of Surrey.

Lehrer, et.al. 2017. Frames, Felds, and Contrasts: New Essays in Semantic and Lexical Organization. New York: Routledge.

Mey, J. L. 1995. Concise Encyclopedia of Pragmatics. Amsterdam: Elsevier.

Mulyadi. 2003. Struktur Semantis Verba Tindakan Bahasa Indonesia. USU Digital Library, 1(1), 1-18.

Mulyadi \& Siregar, R. 2006. Aplikasi Teori Metabahasa Makna Alami dalam Kajian Makna, Jurnal Ilmiah Bahasa dan Sastra Universitas Sumatera Utara, 2(2), 69-75.

Nevalainen, T., \& Traugott, E. C. 2012. The Oxford Handbook of the History of English. Oxford: Oxford University.

Riemer, N. 2008. The Semantics of Polysemy: Reading Meaning in English and Warlpiri. Berlin: Mouton de Guyter.

Sharifian, F., \& Palmer, G. B. 2007. Applied Cultural Linguistics: Implications for Second Language Learning and Intercultural Communication. Amsterdam: John Benjamins Publishing.

Slavcheva, M. 2013. Text, Speech, and Dialogue. Pittsburgh: Springer.

Srinivasan, M., \& Snedeker, J. 2013. Polysemy and the Taxonomic Constraints: Children's Representation of Words that Label Multiple Kinds. San Diego: California University.

Tarigan, K.E. (2019). The Development of Phonological System Made by the Children. Budapest International Research and Critics in Linguistics and Education (BirLE) Journal Vol 2 (2): 338-342.

Tarigan, S.N., and Mulyadi. (2019). The Comparison Question Sentences Between Karonese and English Language: Teory X-Bar. Budapest International Research and Critics in Linguistics and Education (BirLE) Journal Vol 2, No (4): 89-97.

Wierzbicka, A. 1987. Semantics: Primes and Universals. Oxford: Oxford University. 